\title{
Conferências de políticas públicas: um sistema integrado de participação e deliberação?
}

A teoria democrática contemporânea abriga hoje pelo menos duas abordagens que vinculam a presença de espaços participativos à qualidade da democracia ${ }^{1}$. Ambas, a abordagem participativa e a deliberativa, apostam na centralidade desses espaços para conferir, dentre outras coisas, legitimidade às decisões políticas que vinculam uma coletividade. Assim sendo, "uma decisão coletiva só será legítima na medida em que todos aqueles sujeitos a ela tenham o direito, a capacidade e a oportunidade de participar, de forma conseqüente, na deliberação sobre o conteúdo desta decisão" (Dryzek, 2010, p. 14; Habermas, 1996; Cohen e Sabel,1997; Benhabib, 1996).

Tanto a tradição participativa quanto a deliberativa, ao apostarem na centralidade da participação e da discussão para a legitimidade do processo decisório, torna-se ferramentas analíticas úteis para analisarmos mais uma inovação democrática no Brasil contemporâneo: as conferências de políticas públicas.

As conferências de políticas públicas são definidas oficialmente como espaços institucionais de participação e deliberação acerca das diretrizes gerais de uma determinada política pública podendo assumir caráter consultivo ou deliberativo (República Federativa do Brasil, SG-PR/SNAS)². Podem ser

Os dados do presente trabalho são resultados parciais da pesquisa Da constituição do interesse público à busca por justiça social: uma análise das dinâmicas participativa e deliberativa nas Conferências Municipais, Estaduais e Nacionais de Políticas Públicas, coordenada por Cláudia Feres Faria e financiada pela Fundação de Amparo à Pesquisa de Minas Gerais - FAPEMIG.

Disponível em: www.presidencia.gov.br, acessado durante todo o ano de 2010. 
convocadas por lei, decreto, portaria ministerial ou interministerial ou ainda por resolução do respectivo Conselho. Ao regulamentá-las, os órgãos responsáveis pela convocação e realização das Conferências detalham os temas e os objetivos e estabelecem as comissões organizadoras, os cronogramas e os regulamentos para implantação das reuniões municipais, estaduais e/ ou regionais e nacionais, bem como para as eleições de delegados. Neste sentido, as conferências constituem espaços de participação e de deliberação que requerem esforços diferenciados, tanto de mobilização social, quanto de construção da representação social e do diálogo em torno da definição de uma determinada política pública.

Essa diferenciação de formas de ação - participação, representação e deliberação - presentes na dinâmica de uma conferência, bem como a tentativa de integrá-las, coloca desafios não só analíticos como práticos.

Do ponto de vista analítico, embora participação - inclusão de diferentes vozes -, representação - agir em nome do outro - e deliberação - decisões tomadas com base em justificativas publicamente aceitáveis - não constituam formas de ação excludentes, a integração das mesmas não é trivial, gerando um conjunto de tensões (Warren, 2007; Cohen e Fung, 2004).

Do ponto de vista empírico, tal integração exige uma atenção especial na coordenação desses distintos modos de ação. Participação, representação e deliberação precisam ser devidamente compatibilizadas para que se possam alcançar resultados inclusivos e justos. Neste caso, as Conferências tornam-se um lócus de pesquisa e análise singular na medida em que elas não só conectam essas diferentes formas de ação em um mesmo espaço, mas também o fazem em diferentes escalas: do local para o estadual e deste para o nacional.

O objetivo deste artigo é, portanto, avaliar a estrutura institucional destas conferências para aferir como esses espaços integram esses diferentes tipos de ação e se eles conseguem formar um sistema, denominado aqui de sistema integrado de participação e deliberação, entre os diferentes níveis da federação. Esta ideia de sistema tem ganhado proeminência na teoria democrática deliberativa como decorrência da necessidade de conectar a deliberação com outras formas de ação e comunicação em contextos de grande escala. $\mathrm{O}$ potencial e os limites desta ideia serão desenvolvidos na seção 1 deste artigo.

Na seção 2, buscar-se-á analisar em que medida e como parte da literatura sobre políticas públicas, notadamente o diálogo estabelecido entre as contribuições de Kingdon (2003), Sabatier e Jenkins-Smith (1999), Fischer 
(2003) e Hajer e Wagenaar (2003), considera esses diferentes repertórios de ação no processo de constituição da agenda pública.

Na seção 3 deste artigo, analisaremos dois tipos de Conferências, a saber, as Conferências de Mulheres e as Conferências de Assistência Social. Os objetivos, a estrutura institucional, os atores, e os resultados de cada Conferência, nos diferentes níveis da federação, serão investigados com base na análise documental.

Na seção conclusiva, apontaremos comparativamente as potencialidades e os limites dessas conferências em conformarem um sistema integrado que, segundo Dryzek (2010), só ocorrerá se for capaz de acomodar um tipo de deliberação que seja autêntica - induza a reflexão sobre preferências de forma não coercitiva; se ele for inclusivo - ofereça oportunidade e habilidade para todos os atores afetados (ou seus representantes) participarem; e se ele produzir resultados políticos - sejam eles na forma de leis ou de políticas públicas (Dryzek, 2010, p. 10).

\section{O "turn" deliberativo e a ideia de sistema integrado de deliberação}

Tornou-se rotineiro encontrarmos, após o giro deliberativo na teoria democrática, um conjunto de pesquisas e artigos que buscam precisar os elementos da deliberação à luz das evidências empíricas (Gastil e Levine, 2005; Rosenberg, 2007). Uma das consequências positivas desse esforço é pensar a deliberação "enquanto um entre diversos momentos do processo político" e, consequentemente, analisar sua relação com os outros diversos momentos. Autores como Hendriks (2006), Mansbridge (2007; 2010) e Goodin (2008) são expoentes importantes desta ideia, uma vez que buscam localizar a deliberação no interior de um processo político mais amplo.

Parte desse esforço analítico tem sua origem no problema da escala (Dryzek, 2010), mas não só. A diferenciação de formas de ação também conta. Participação e deliberação, embora sejam atividades que têm como objetivo melhorar a qualidade da vida pública, operam por meios diferentes, tal qual afirmam Papadopoulos e Warin (2007). Segundo os autores, a participação pressupõe um envolvimento direto, amplo e sustentado dos cidadãos nas questões públicas. Seus defensores preocupam-se mais com a inclusão como condição para a efetividade e a legitimidade da política do que com a qualidade das razões apresentadas para justificar as preferências dos atores. Os deliberativos, por sua vez, estão mais preocupados com a qualidade da 
discussão e da interação que irão gerar as escolhas políticas (Papadopoulos e Warin, 2007, p. 450-451).

Cohen e Fung (2004), assim como Fishkin (1991), identificam também diferenças entre essas atividades. Segundo os autores, melhorar a qualidade da deliberação e expandir a participação constitui objetivos contraditórios. Passeatas, demonstrações, referendos, recall, etc. são mecanismos que promovem a participação ampla, mas não a deliberação. Expressam a vontade, mas não a razão ponderada. Ao mesmo tempo, fóruns menores são mais propícios à troca de razões por meio da deliberação, mas operam em pequenas escalas e à custa do insulamento do público geral (Cohen e Fung, 2004, p. 26-27).

Para dar conta dessa tensão e, ao mesmo tempo, produzir uma opinião pública mais crítica e informada, autores como Young (2002) e Fung (2005) apostam em políticas que envolvam tanto a dimensão participativa, como a deliberativa, além da representativa, sem, contudo, precisar a forma como deve operar tais atividades ${ }^{3}$. Ganham destaque, portanto, os modelos oferecidos pelos autores já mencionados. A preocupação deles não reside somente na compatibilização dessas formas de ação, mas, como já ressaltado, na localização da deliberação em um processo decisório mais amplo que pode envolver tanto a resistência e o conflito, próprios à participação, quanto a cooperação e o diálogo, próprios à deliberação. O uso de cada um dependerá do contexto em que operam, assim como da natureza das políticas em questão (Holzinger, 2005; Hendriks, 2006).

O modelo integrado de deliberação de Hendriks (2006) constitui a primeira proposta aqui analisada de compatibilizar esferas múltiplas de deliberação. Partindo de um conceito espacial de deliberação, a autora afirma que tal prática pode ocorrer em vários espaços públicos, incluindo parlamentos, partidos, fóruns, igrejas, conformando um sistema que envolve um conjunto de arenas através das quais tipos particulares de atividades ocorrem como, por exemplo, as práticas comunicativas que promovem a reflexão crítica e política.

Desta forma, o sistema se caracteriza por múltiplas esferas discursivas que podem ser formais, informais ou mistas e cujas formas de comunicação

Fung (2005) propõe uma governança democrática que envolve os três tipos de atividade, mas não apresenta formas sistemáticas de integrá-las. Young (2000) considera as duas outras atividades, principalmente como forma de qualificar a representação, sem contudo se preocupar em mostrar como elas podem se conectar. 
também variam, indo desde o questionamento, a contestação e a negociação até o consenso. Algumas são mais estruturadas que as outras; algumas são mais públicas e inclusivas e algumas são promovidas pelo estado ao passo que outras, pelos atores da sociedade civil.

Uma vez que os atores possuem disposições variadas para deliberar nas diferentes esferas, é importante, adverte a autora, que o sistema como um todo promova a diversidade de espaços deliberativos. As esferas que combinam modos de deliberação formal e informal são importantes, pois, apesar das tensões, podem conectar mundos deliberativos diferentes para os quais a autora denomina de macro e micro, povoados por atores diferentes: ativistas, grupos de interesses, corporações, mídia, no macro e parlamentares, consultores, acadêmicos, no micro. Tais espaços, ao entrarem em contato entre si e com cidadãos individuais, podem encorajar a troca de ideias entre atores com perspectivas diferentes, conectando o discurso público mais amplo com conversações e decisões das elites políticas. Este intercâmbio reflete uma constelação de discursos envoltos em um mesmo problema (Hendriks, 2006, p. 498). A autora busca, com isso, diferenciar seu modelo dos enclaves deliberativos, buscando conectar esferas que podem ser mais ou menos inclusivas ou mais ou menos populistas.

O sistema deliberativo oferecido por Mansbridge (1999; 2007; 2010) é composto por discursos formais, bem como falas informais e cotidianas entre atores comuns e políticos, tais como representados e representantes eleitos e não eleitos, ativistas e não ativistas e os mídia. Sua função é permitir que os atores compreendam melhor o que querem e necessitam, tanto individual quanto coletivamente. O objetivo da deliberação passa a ser, portanto, clarear o conflito e tentar conformá-lo.

Assim como o objetivo da deliberação não se encerra mais na busca do consenso em torno do bem-comum, o conceito de deliberação também passa por mudanças, abrigando o autointeresse, o conflito decorrente dos interesses materiais e das diferenças de opiniões. Formas de agregação democrática, além de algum grau de informalidade na discussão passam a ser consideradas legítimas ${ }^{4}$.

Para que as mudanças defendidas façam sentido, o sistema deve ser julgado segundo padrões mais flexíveis, acomodando o caráter mais informal das

Uma crítica a esse conceito expandido de deliberação encontra-se em Faria (2010). 
partes no seu interior. Não obstante, ele não pode perder de vista critérios importantes através dos quais se julga a boa deliberação. Critérios como publicidade, reciprocidade e controle se mantêm, assim como o conceito de razão pública, que, entretanto, deve ser reformulado de modo a envolver a emoção e a paixão (Mansbrigde, 2010).

Goodin (2008) oferece igualmente um sistema sequenciado de momentos deliberativos que se contrapõe à versão clássica da democracia deliberativa que considera o agente deliberativo como único, buscando um objetivo compartilhado por todas as partes componentes desse mesmo agente.

Apoiando-se na mesma motivação de Mansbridge (2010), ou seja, a busca de maior realismo para a teoria deliberativa ${ }^{5}$, o autor argumentará que sendo a política composta de agentes plurais com interesses conflitantes, desempenhando papéis diversificados em todo o processo político, o processo deliberativo deve ser visto igualmente de forma distribuída, com diferentes agentes desempenhando papéis deliberativos também diferentes. A justificativa para tal modelo repousa na crença, comum na teoria democrática, de que em grande escala, a deliberação interpessoal deve assumir formas delegadas.

Seu exemplo paradigmático é o Legislativo. Nestes espaços, segundo Goodin, as deliberações são distribuídas entre comissões e plenário, cada um deles com regras próprias em função tanto do tamanho quanto das diferentes funções que desempenham. Mas, como ele, é possível pensar outros espaços onde as deliberações em subunidades servem como inputs para a deliberação em grupos maiores, com novas responsabilidades deliberativas. Como as comissões e o plenário no Congresso, nestes outros espaços, as regras e a forma de conduzir a deliberação também não são as mesmas.

Goodin (2008) assegura que podemos esperar realisticamente que virtudes deliberativas diferentes sejam encontradas em diferentes estágios do processo deliberativo, embora reafirmando a diferença de seu modelo do ideal deliberativo.

Assim como Mansbridge (2007), o autor também acredita que, apesar de a comunicação entre as partes não ser um jogo cooperativo, é possível a formação de um compromisso mutuamente aceitável entre elas, embora

Mansbridge (2007) faz, inclusive, uma diferença entre teoria democrática deliberativa e deliberação democrática através da qual estabelece as diferenças entre os pressupostos clássicos da deliberação e do modelo mais realista que ela está oferecendo. 
nunca o consenso seja racionalmente motivado. As partes buscarão negociar e barganhar interesses e não somente trocar respeitosamente razões. $\mathrm{O}$ contexto é, portanto, caracterizado pelo conflito, embora não só, pois existirá sempre espaço para a concessão recíproca e para os argumentos razoáveis na construção de decisão vinculantes.

O Quadro 1 visa oferecer uma síntese desses modelos.

Quadro 1 - Modelos de deliberação

\begin{tabular}{c|c|c|c}
\hline modelos & características & objetivos da deliberação & meios \\
\hline $\begin{array}{c}\text { modelo integrado } \\
\text { de deliberação } \\
\text { C. Hendriks } \\
(2006)\end{array}$ & $\begin{array}{c}\text { Múltiplas esferas } \\
\text { discursivas, que podem } \\
\text { ser formais, informais ou } \\
\text { mistas. }\end{array}$ & $\begin{array}{c}\text { Promover reflexão crítica e } \\
\text { política. }\end{array}$ & $\begin{array}{c}\text { Formas de comunicação } \\
\text { variadas indo desde 0 } \\
\text { questionamento, a con- } \\
\text { testação, a negociação } \\
\text { até 0 consenso. }\end{array}$ \\
\hline $\begin{array}{c}\text { sistema } \\
\text { deliberativo }\end{array}$ & $\begin{array}{c}\text { Consiste em discursos } \\
\text { formais, bem como falas } \\
\text { informais e cotidianas } \\
\text { entre atores comuns } \\
\text { (1999; 2007; 2009) }\end{array}$ & $\begin{array}{c}\text { Clarear o confliticos. } \\
\text { conformá-lo, e não mais a } \\
\text { busca do consenso em torno } \\
\text { do bem-comum. }\end{array}$ & $\begin{array}{c}\text { Deliberação via razão, } \\
\text { emoção e outras formas } \\
\text { de comunicação, tais } \\
\text { com a barganha. }\end{array}$ \\
\hline $\begin{array}{c}\text { sistema sequencia- } \\
\text { do de momentos } \\
\text { deliberativos } \\
\text { R. Goodin } \\
(2008)\end{array}$ & $\begin{array}{c}\text { Esferas diferentes com } \\
\text { discursos diferentes. }\end{array}$ & $\begin{array}{c}\text { Compromisso mutuamente } \\
\text { aceitável entre as partes, } \\
\text { embora nunca o consenso } \\
\text { racionalmente motivado. }\end{array}$ & $\begin{array}{c}\text { As partes buscarão } \\
\text { negociar e barganhar in- } \\
\text { teresses e não somente } \\
\text { razões. }\end{array}$ \\
\hline
\end{tabular}

Fonte: Faria (2010).

É possível afirmar que os três modelos apresentados buscam, com maior ou menor intensidade, vincular tipos distintos de comunicação e discursos em esferas diferentes que conformarão os sistemas propostos. Formas de comunicação mais próximas ao tipo participativo, como a contestação, a demonstração e a negociação, devem ser conectadas com formas mais consensuais de solução de conflitos próprias às arenas mais deliberativas. $\mathrm{O}$ pressuposto por trás desse esforço analítico consiste no reconhecimento de que um sistema integrado de deliberação só poderá existir se conviver com padrões de ação e de comunicação diferentes em espaços que sejam mais propícios para um ou outro tipo de ação. 
Ademais, a literatura em tela prescreve que esses diferentes espaços operem de forma inclusiva, ou seja, a construção de uma agenda e/ou o processo decisório que neles ocorrem deve incluir todos os atores que estejam diretamente ligados a esses processos. Esses atores devem ainda participar das discussões e das decisões em condições de igualdade e sem nenhum tipo de coerção interna e externa. Essa ideia tem sido gradualmente incorporada pela literatura de políticas públicas, que, até recentemente, somente levava em conta atores considerados como politicamente relevantes. Na próxima seção, esse argumento será desenvolvido com o intuito de apontar para a tensão existente entre as abordagens participativa e deliberativa e a literatura de políticas públicas.

\section{Padrões de ação e comunicação e políticas públicas}

No campo de análise das políticas públicas, os padrões de ação de atores governamentais, políticos e sociais envolvidos nos processos decisórios constituem elementos analíticos importantes desde as primeiras investigações nesse campo, desenvolvidas a partir da década de 1960. Inicialmente, os trabalhos produzidos identificavam exclusivamente os atores considerados politicamente relevantes para esse processo, os quais representavam, em maior ou menor grau, o Estado e os grupos de interesse vinculados à política pública em questão.

Com o avanço dos debates e das investigações sobre políticas públicas nos anos 70, em resposta, sobretudo, às mudanças políticas e socioeconômicas ocorridas nesse período, novas interpretações passaram a compor o leque de abordagens preocupadas em compreender e explicar os processos de formação e de mudanças das políticas. Dentre as mais proeminentes, estavam a abordagem institucional, de redes, da teoria da escolha racional e a abordagem baseada no papel das ideias ${ }^{6}$ e do conhecimento nesses processos (John, 1999).

Essas teorias deram origem a uma gama diversificada de interpretações, que buscaram explicar as políticas públicas atribuindo menor ou maior centralidade ao papel dos atores governamentais, políticos e sociais na escolha e na mudança das mesmas. Dentre esses trabalhos, ganharam destaque por sua aplicabilidade, sofisticação analítica e capacidade de gerar novas pesquisas empíricas: (a) a abordagem dos Múltiplos Fluxos (multiple-streams), desenvolvida por John Kingdon (2003), que trata do processo de formação

6 As ideias consistem no conjunto de paradigmas cognitivos e visões de mundo, quadros normativos e cognitivos e ideias programáticas que condicionam o comportamento dos indivíduos (Campbell, 2002). 
da agenda de políticas públicas, e (b) a abordagem das advocacy coalitions, desenvolvida por Paul A. Sabatier e por Hank Jenkins-Smith (1999), que busca explicar as mudanças nas políticas.

O Modelo de Múltiplos Fluxos de Kingdon (2003) analisa o processo de formação da agenda de políticas públicas dos governos liberais democráticos, com ênfase na dinâmica das ideias e do discurso. Tendo como referência o modelo de comportamento organizacional da Lata de Lixo ${ }^{7}$ (Cohen, March e Olsen, 1972), Kingdon argumenta que o processo de formação da agenda governamental resulta da combinação de três fluxos: (1) o fluxo de problemas, (2) o fluxo de alternativas e (3) o fluxo político. O primeiro diz respeito às formas pelas quais os tomadores de decisão fixam sua atenção em determinadas questões sociais e as traduzem em problemas sociais. $\mathrm{O}$ fluxo de alternativas corresponde ao processo de geração de alternativas e propostas de política pública nas comunidades de política. Já o fluxo político compreende os processos políticos desenvolvidos em âmbito governamental, baseados em barganhas e negociações políticas.

No fluxo de problemas, Kingdon ressalta a centralidade, dentre outros atores, da atuação dos grupos de interesses, que pressionam e chamam atenção dos policy makers para suas questões, no intuito de inseri-las na agenda governamental ${ }^{8}$. No fluxo de alternativas, o autor chama atenção para o papel de outros atores, tais como pesquisadores, analistas e acadêmicos, que, junto aos demais, criam as alternativas para os problemas. Ao compartilharem ideias, propostas e pesquisas uns com outros conformam aquilo que o autor denomina de comunidades de políticas compostas por especialistas de uma determinada área de política pública. Quando esses atores investem sua energia no sentido de sensibilizar os governantes e os atores governamentais, eles passam a ser denominados de empreendedores de política ${ }^{9}$. Esses são

\footnotetext{
O Modelo de comportamento organizacional da Lata de Lixo de Cohen, March e Olsen (1972) explica o processo de tomada de decisão em anarquias organizadas a partir de quatro fluxos: (1) o fluxo de problemas, (2) o de escolhas, (3) o fluxo de energia dos participantes e (4) o nível de fluxo de soluções.

8 Kingdon (2003) aponta também como determinante a vontade política dos atores políticos que querem se reeleger; a vontade dos burocratas que propõem iniciativas para promovê-los em seus cargos e os altos custos políticos, sociais e orçamentários para solucioná-lo.

Kingdon (2003) identifica dois tipos de empreendedores de política: os visíveis, que são aqueles que recebem considerável atenção da imprensa e do público, e os invisíveis, que formam as comunidades nas quais as ideias são geradas. Como atores visíveis, o autor sugere o chefe do Executivo, os ministros, os atores do Legislativo, a mídia, os grupos de interesse e os partidos políticos. Como invisíveis, o autor identifica os burocratas, os analistas e os acadêmicos.
} 
responsáveis por propor soluções para os problemas, mobilizar opiniões e instituições e assegurar que suas ideias entrem na agenda. Além disso, eles constituem, nessa proposta de Kingdon, os principais atores do processo de formação da agenda governamental, o qual resulta da combinação do fluxo de problemas, de alternativas e do fluxo político em um processo denominado coupling, no qual janelas de política (Policy Windows) se abrem e devem ser rapidamente aproveitadas pelos empreendedores de política.

Sabatier e Jenkins-Smith (1999) formularam o Modelo de Advocacy Coalitions (ACF), com o objetivo de avançar o debate por meio da análise dos momentos de mudança na agenda dos governos. Nesse modelo, é atribuída centralidade aos atores políticos, governamentais e sociais que estão vinculados, em alguma medida, às políticas públicas, uma vez que, para esses autores, as mudanças nas políticas públicas resultam de alterações nos padrões de relação entre esses atores, os quais se encontram agrupados em coalizões de defesa no interior de cada subsistema de política.

As coalizões de defesa são formadas a partir das interações dos atores políticos, sociais e governamentais dentro de cada subsistema de política. Elas consistem em alianças de grupos que apresentam as mesmas ideias e interesses em relação à determinada política, isto é, em redes de atores que compartilham valores e conhecimento que os distinguem das demais. Nos subsistemas de política, as coalizões podem ser consensuais ou dominadas por uma única coalizão, sendo que, no último caso, elas competem entre si e pressionam para que suas crenças se tornem propostas de políticas públicas e entrem na agenda governamental.

Nesse processo, a capacidade de influenciar a decisão governamental depende da capacidade financeira, intelectual (expertise), política (como o número de apoiadores e a capacidade de mobilização) e institucional (como a autoridade legal) que as coalizões dispõem.

Essa capacidade, por sua vez, pode ser afetada por (1) por eventos externos ao subsistema que independem da atuação das coalizões, tais como (1) as mudanças nas condições socioeconômicas, que impactam a composição e os recursos das coalizões de cada subsistema político; (2) as mudanças na estrutura de governo, que alteram a composição e os recursos políticos dos atores estatais; e (3) as decisões políticas e os impactos de outros subsistemas, que afetam a composição e os recursos das coalizões de determinado subsistema; e/ou (2) por mudanças em parâmetros relativamente estáveis como os 
atributos básicos do problema, a distribuição básica dos recursos naturais, a estrutura sociocultural de valores fundamentais, a estrutura social e as regras constitucionais básicas. Deste modo, as mudanças na agenda de políticas públicas resultam de mudanças nos padrões de interação entre coalizões no interior de subsistemas de política, gerados, em maior medida, por eventos externos e, em menor, por mudanças em parâmetros relativamente estáveis.

A importância dessa literatura para o objeto em análise diz respeito à centralidade que ela confere ao envolvimento de um conjunto de atores sociais e políticos em "comunidades de políticas" ou "coalizões de defesa" na determinação da agenda pública e do processo de mudança da mesma. Ao enfatizar alianças de diferentes grupos que compartilham interesses, ideias e crenças políticas, tal perspectiva amplia, de fato, o número de participantes no processo de construção da agenda, uma vez que inclui novos atores além dos tradicionalmente considerados, tais como governo, burocratas e técnicos. Em que pese a inclusão no número e tipos de atores envolvidos, os autores filiados ao campo discursivo de análise sobre políticas públicas (Hajer e Wagenaar, 2003; Fischer, 2003; Goodin, 2008) ressentem da ausência, nas abordagens supracitadas, de explicações acerca da dimensão interativa através da qual são estruturados os problemas, formadas as coalizões e mudadas as agendas.

Segundo Fischer (2003), os modelos apresentados desconsideram o contexto no qual as comunidades ou coalizões de defesa são formadas e, assim, prestam pouca ou nenhuma atenção às formas nas quais elas se estruturam. Além de crenças, afirma o autor, narrativas, discursos e histórias contadas constituem também meios de interação que impactam o processo de descoberta e formatação dos problemas, bem como de orientação das coalizões a serem formadas (Fischer, 2003, p. 103).

A deliberação torna-se, assim, uma forma de interação importante na medida em que ela pode promover contextos de "descobertas públicas" por meio de um processo de troca de argumentos e de aprendizado social sobre como estruturar os problemas e as possibilidades públicas de resolvê-los (Fischer, 2003, p. 103). Ademais, nesta abordagem, adverte Fischer (2003), as coalisões políticas são reproduzidas e transformados via um conjunto amplo de atores que não necessariamente se encontram face a face, mas que através de suas atividades discursivas reforçam um conjunto particular de narrativas em um determinado campo político (Fischer, 2003, p. 106). Sendo assim, tais narrativas podem ser representadas em diferentes espaços dando 
densidade à ideia de um sistema integrado de participação e deliberação, no qual nem todos estão presentes em todos os lugares, mas podem ser representados pelas ideias, crenças e discursos construídos pelos atores afetados nesses diferentes espaços ${ }^{10}$.

Pensar a construção da agenda de políticas públicas como uma prática participativa e argumentativa requer compreender também os contextos nos quais tais práticas ocorrem. Este é o objetivo da próxima seção deste artigo: avaliar as "configurações institucionais" nas quais se dão as interações entre os atores sociais e políticos envolvidos em dois tipos diferentes de políticas públicas, a saber, as Conferências de Políticas para as Mulheres e as Conferências de Assistência Social. Tal análise basear-se-á em um conjunto de regras que estruturam estes espaços e, como tal, impactam as dinâmicas participativa e deliberativa que ocorrem no interior dos mesmos.

\section{Conferências nacionais, estaduais e municipais: um sistema integrado de participação e de deliberação?}

As Conferências de Políticas Públicas foram criadas no governo Vargas, pela Lei $\mathrm{n}^{\circ} 378$, de 13 de Janeiro de 1937, com o objetivo de facilitar o conhecimento do Governo Federal acerca das atividades relativas à saúde e de orientá-lo na execução dos serviços locais de saúde. Nessa lei, ficou definido que os encontros seriam convocados pelo Presidente da República e contariam com a participação de representantes do governo dos três níveis da federação e de representantes dos grupos sociais relacionados à área e tema da Conferência (Sayd, Vieira Junior e Velandia, 1998).

Desde sua criação até 2010, já foram realizadas 102 conferências nacionais e centenas de milhares de conferências intermediárias, nas esferas municipais e estaduais. Do total de encontros nacionais, 9 aconteceram entre $1941 \mathrm{e}$ 1988 - 8 delas referentes ao tema saúde e 1 de Ciência e Tecnologia; 27 foram organizados entre 1988 e 2002 e debateram políticas de Saúde, Assistência Social, Direitos Humanos, Direitos da Criança e do Adolescente e Segurança Alimentar e Nutricional; e as outras 67 Conferências, que correspondem a 66\% do total, ocorreram entre 2003 e 2010, nos governos Lula (República Federativa do Brasil, 2010). Neste governo, as conferências tornaram-se uma das principais arenas de interlocução entre governo e sociedade civil com

\footnotetext{
${ }^{10}$ A ideia de sistema se difere da ideia de redes pelo fato de permitir diferenciar espaços, ações e públicos que na rede aparecem embaralhados. Para ver as consequências de tal distinção, ver Dryzek (2010).
} 
o objetivo de debater e deliberar propostas para formulação de políticas públicas, propor novas ações do governo para compor o Plano Plurianual de Ação (PPA) e avaliar as políticas aprovadas em encontros anteriores.

Diante do universo de conferências já realizadas, optou-se, neste trabalho, por analisar as Conferências de Assistência Social e de Políticas para Mulheres, mais especificamente a $7^{\text {a }}$ Conferência Nacional de Assistência Social, a $8^{\text {a }}$ Conferência Estadual e a $8^{\text {a }}$ Conferência Municipal de Assistência Social ${ }^{11}$, bem como a $2^{\text {a }}$ Conferência de Políticas para Mulheres, nos três níveis de governo; todas organizadas durante o segundo mandato de Lula.

A política de assistência social é garantida constitucionalmente e, portanto, as conferências sobre o tema devem ser realizadas periodicamente e suas resoluções têm caráter vinculatório, devendo ser transformadas em decisões do Executivo. A política para mulheres, por sua vez, ainda não consiste em uma política de Estado e, por isso, as resoluções produzidas nas Conferências dependem de um conjunto de variáveis para se tornarem decisões governamentais.

Sabe-se que tal diferença impacta não só a capacidade das conferências de produzirem resultados, mas também as próprias dinâmicas participativa, representativa e deliberativa ${ }^{12}$, gerando problemas, consequentemente, para a formação de um sistema integrado nos moldes propostos neste artigo. Não obstante, o foco aqui proposto não é uma análise dessas dinâmicas, mas da existência de espaços cujas regras promovem ou não tais dinâmicas e sua integração em um sistema. Da mesma forma, não avaliaremos a implementação ou não das resoluções das conferências analisadas, mas somente a coerência entre aquilo proposto nas etapas municipais, estaduais e seu resultado final nas conferências nacionais. Neste sentido, examinaremos os objetivos, a estrutura institucional, os atores e os resultados de cada uma dessas conferências, a partir de análise documental.

Os objetivos e o formato institucional que as Conferências assumem, bem como as normas que regulam a dinâmica participativa, deliberativa e representativa são regulados, em geral, pelas leis que convocam esses espaços e por

1 Em 2009, foram realizadas a 7a Conferência Nacional de Assistência Social, a 8a Conferencia Estadual de Minas Gerais e a 8a Conferência Municipal de Belo Horizonte. A política de assistência social não apresenta, como na política para as mulheres, a mesma correspondência entre as Conferências nos três níveis da federação.

12 Para uma avaliação das variáveis que impactam as dinâmicas participativa, deliberativa e representativa das instituições participativas, ver Faria e Ribeiro (2010). 
seus regimentos internos (doravante, RI). Através deles são estabelecidos os objetivos do encontro; os eixos temáticos a serem debatidos; as etapas e as datas de realização dos debates; o número e a composição de representantes civis e estatais por unidade da federação; a dinâmica deliberativa sobre a formulação e o encaminhamento das propostas aprovadas. Em todos os níveis da federação, esse documento deve passar pelo crivo da plenária da conferência, que pode aprová-lo na íntegra, aprová-lo com mudanças ou rejeitá-lo. Neste último caso, os delegados-representantes devem formular e aprovar outro regimento antes de dar continuidade aos trabalhos. Sendo assim, esse documento torna-se uma fonte documental importante para aferirmos a estruturação dos momentos participativos, representativos e deliberativos, bem como a capacidade de integrar os mesmos em um sistema.

Nas Conferências Municipais de Assistência Social, o regimento interno é elaborado pelo Conselho Municipal da área. No âmbito estadual, esse documento é elaborado pelo Conselho Estadual de Assistência Social e pela Secretaria de Estado de Desenvolvimento Social (SEDESE), no caso de Minas Gerais. Por fim, o RI da Conferência Nacional de Assistência Social é de responsabilidade do Ministério do Desenvolvimento Social e Combate à Fome e conta com o apoio do Conselho Nacional da área. Essas instituições também são responsáveis por coordenar e realizar as conferências nos respectivos níveis da federação, como mostram os dados do Quadro 2.

Quadro 2 - Local, ano e coordenação das Conferências de Assistência Social

\begin{tabular}{c|c|c|c}
\hline variável & municipal & estadual & nacional \\
\hline ano & 2009 & 2009 & 2009 \\
\hline local & Belo Horizonte & Belo Horizonte & Brasília \\
\hline $\begin{array}{c}\text { convocação e } \\
\text { coordenação }\end{array}$ & CMAS & CEAS e SEDESE & $\begin{array}{c}\text { Ministério do Desenvolvimento } \\
\text { Social e Combate à Fome }\end{array}$ \\
\hline
\end{tabular}

Fonte: Regimento Interno das Conferências de Assistência Social.

O regimento interno da Conferência Municipal de Políticas para Mulheres é formulado pela Secretaria Municipal de Políticas Sociais, em parceria com a Secretaria Municipal Adjunta de Direitos de Cidadania, da Coordenadoria dos Direitos das Mulheres e do Conselho Municipal de Direitos das Mulheres. No âmbito estadual, em Minas Gerais, esse documento é elaborado pela SEDESE, pela Coordenadoria Especial de Promoção da Defesa da Mulher, 
pela Assembleia Legislativa de Minas Gerais e pelo Conselho Estadual da Mulher. O RI da conferência nacional, por sua vez, é elaborado pela Secretaria Especial de Políticas para Mulheres e pela Secretaria Geral da Presidência da República, que contam com o apoio do Conselho Nacional da área. Essas instituições também são responsáveis por coordenar e realizar as conferências nos respectivos níveis da federação, como atestam os dados do Quadro 3.

Quadro 3 - Local, ano e Coordenação das Conferências de Políticas para Mulheres

\begin{tabular}{|c|c|c|c|}
\hline variável & municipal & estadual & nacional \\
\hline ano & 2007 & 2007 & 2007 \\
\hline local & Belo Horizonte & Belo Horizonte & Brasília \\
\hline $\begin{array}{l}\text { convocação e } \\
\text { coordenação }\end{array}$ & $\begin{array}{l}\text { Secretaria Municipal de Políticas } \\
\text { Sociais, por meio da Secretaria } \\
\text { Municipal Adjunta de Direitos de } \\
\text { Cidadania, da Coordenadoria dos } \\
\text { Direitos da Mulher e do Conselho } \\
\text { Municipal de Direitos da Mulher. }\end{array}$ & $\begin{array}{l}\text { SEDESE, Coordenadoria } \\
\text { Especial de Promoção e } \\
\text { Defesa da Mulher, As- } \\
\text { sembleia Legislativa de } \\
\text { Minas Gerais e Conselho } \\
\text { Estadual da Mulher }\end{array}$ & $\begin{array}{l}\text { Secretaria Especial de } \\
\text { Políticas para as Mulhe- } \\
\text { res, Secretaria Geral da } \\
\text { Presidência da República } \\
\text { e Conselho Nacional dos } \\
\text { Direitos da Mulher }\end{array}$ \\
\hline
\end{tabular}

Fonte: Regimento Interno das Conferências de Assistência Social.

\section{Objetivos das Conferências de Assistência Social (CAS) e de Políticas para Mulheres}

O objetivo geral da CAS foi avaliar e propor diretrizes para o aperfeiçoamento do Sistema Único de Assistência Social (SUAS) na perspectiva da participação e do controle social. Este foi desdobrado em objetivos específicos, discutidos e debatidos em cada etapa das Conferências. Da mesma forma, a $2^{\text {a }}$ Conferência Nacional de Políticas para Mulheres, cujo objetivo geral foi a avaliação e o aprimoramento do Plano Nacional de Políticas para Mulheres (PNPM) na perspectiva da participação das mulheres em espaços de poder, discutiu e debateu seus objetivos específicos nas etapas municipal, estadual e nacional.

Os Quadros 4 e 5 retratam os objetivos das Conferências de Assistência Social e de Políticas para Mulheres, respectivamente, em cada nível da federação.

Como podemos depreender do Quadro 4, os objetivos específicos das CAS, em todos os níveis, dizem respeito, em primeiro lugar, às formas e/ou lócus de ação para aperfeiçoar o SUAS sob o ponto de vista da participação 
e do controle social. Neste sentido, nos três níveis de governo, propôs-se discutir e avaliar a participação e o controle dos atores em questões como o orçamento e o cofinanciamento para a implementação do Plano Decenal da Assistência Social; discutir a atuação do trabalhador da área para abrigar melhor a participação dos usuários na implementação do SUAS, bem como discutir o papel dos Conselhos e das entidades de Assistência Social. No que diz respeito aos Conselhos, o debate está concentrado na composição, representatividade e dinâmica dos mesmos, enquanto o debate sobre as entidades diz respeito à atuação das mesmas na execução da política e na democratização da gestão interna do SUAS.

Quadro 4 - Objetivos específicos das Conferências de Assistência Social

\begin{tabular}{|c|c|c|c|}
\hline variável & municipal & estadual & nacional \\
\hline objetivos & $\begin{array}{l}\text { (1) Avaliar e propor } \\
\text { diretrizes para } 0 \text { aper- } \\
\text { feiçoamento do SUAS na } \\
\text { perspectiva do controle } \\
\text { social e da participação. } \\
\text { (2) Avaliar a implemen- } \\
\text { tação das deliberações da } \\
\text { VII Conferência Municipal; } \\
\text { (3) Eleger delegados } \\
\text { para a VIII Conferência } \\
\text { Regional Estadual. }\end{array}$ & $\begin{array}{l}\text { (1) Discutir e avaliar a participação popular e o } \\
\text { exercício do controle social no âmbito do SUAS; } \\
\text { (2) Avaliar a efetivação dos dez direitos socioas- } \\
\text { sistenciais aprovados na } 4 \text { a Conferência Nacional; } \\
\text { (3) Discutir e avaliar a participação popular e } \\
\text { o controle social em relação ao orçamento } \\
\text { e ao cofinanciamento do Plano Decenal; } \\
\text { (4) Debater a atuação do trabalhador } \\
\text { da Assistência Social; } \\
\text { (5) Discutir a gestão, instrumentos e processos } \\
\text { de trabalho no âmbito do SUAS na perspectiva } \\
\text { dos direitos dos trabalhadores; } \\
\text { (6) Discutir e avaliar a representatividade, } \\
\text { a composição, a dinâmica e o processo de } \\
\text { escolha dos membros dos Conselhos; } \\
\text { (7) Discutir a atuação das entidades } \\
\text { de Assistência Social; e } \\
\text { (8) Conhecer e debater experiências de } \\
\text { implementação do SUAS, que envolvam a } \\
\text { participação popular e o controle social. }\end{array}$ & $\begin{array}{c}\text { Mesmos } \\
\text { objetivos } \\
\text { específicos da } \\
\text { etapa estadual }\end{array}$ \\
\hline
\end{tabular}

Fonte: Regimento Interno das Conferências de Assistência Social.

No que diz respeito às Conferências de Políticas para as Mulheres, neste segundo encontro realizado em 2007, os objetivos específicos buscaram sistematizar um conjunto de ações que viabilizassem o aprimoramento do Plano Nacional de Políticas para Mulheres (PNPM) na perspectiva da participação das mulheres em espaços de poder, objetivo geral dessas Confe- 
rências. Neste caso, tanto na etapa municipal e estadual como na nacional, buscou-se retomar os princípios e diretrizes aprovadas na $1{ }^{\text {a }} \mathrm{CNPM}$; avaliar a implementação do PNPM - 2004/2007; apresentar propostas de alteração do conteúdo e da forma de execução do PNPM, sempre tendo como meta a ampliação do espaço de participação da mulher no poder (Quadro 5).

Quadro 5 - Objetivos específicos da 2a Conferência de Política para Mulheres

\begin{tabular}{c|c|c|c}
\hline variável & municipal & estadual & nacional \\
\hline \multirow{6}{*}{ objetivos } & (1) Analisar e repactuar & (1) Analisar e repactuar os princípios e & \\
& os princípios e diretrizes & diretrizes aprovados na I CNPM; & \\
& aprovados na I CNPM; & (2) Avaliar a implementação do & Mesmos \\
& (2) Avaliar a implementação & PNPM de 2004 a 2007; & objetivos \\
& do PNPM de 2004 a 2007; & (3) Apresentar propostas de & específicos \\
& (3) Apresentar propostas de & alteração do conteúdo do PNPM & descritos \\
& alteração do conteúdo do PNPM & e da sua forma de execução; e & nas etapas \\
& (4) Analisar a participação & (4) Analisar a participação política & anteriores. \\
& política das mulheres nos espaços & das mulheres nos espaços de poder & \\
& de poder e elaborarar propostas para ampliar & \\
& para ampliar sua inserção; & sua inserção; & \\
\hline
\end{tabular}

Fonte: Regimento Interno das Conferências de Políticas para Mulheres.

\section{Estrutura Institucional das CAS e das Conferências de Políticas para Mulheres}

Do ponto de vista formal, todas as discussões em torno dos objetivos, bem como da implementação dos mesmos, ocorrem em etapas encadeadas: das Pré-conferências para as Conferências Municipais, destas paras as Regionais, Estadual e Nacional, como se pode ver nos Quadros 6 e 7 a seguir.

Na Política de Assistência Social (Quadro 6) devem ser realizadas Pré-Conferências regionais preparatórias em nível municipal, seguidas pela Conferência Municipal. Ambas são organizadas pelas Comissões (1) Organizadora, (2) Técnica (ou temática); (3) Administrativa e (4) de Comunicação e por (5) subcomissões, e apresentam uma dinâmica que envolve a Plenária de Abertura, Grupos de Trabalho (no caso, 4 GTs) e a Plenária Final, cujo produto é o relatório final. Este documento é encaminhado para o Conselho Estadual de Assistência Social, o qual é responsável por reunir e sistematizar todas as propostas aprovadas nas conferências municipais em um único documento para ser apreciado no encontro estadual. 
A Conferência Estadual em Minas Gerais é precedida por Conferências Regionais. Apenas os municípios que realizaram conferências municipais ${ }^{13}$ podem participar do encontro regional e estadual. Este último também é organizado pela Comissão (1) Organizadora, (2) Técnica (ou temática); (3) Administrativa e (4) de Comunicação e por (5) subcomissões, e compreende uma Plenária Inicial, Grupos de Trabalho - no caso, 20 GTs - e a Plenária Final. Assim como nas conferências municipais, da plenária final resulta um relatório final, com as propostas e moções aprovadas no encontro. Este documento é encaminhado para o Conselho Nacional, que é o responsável por reunir as propostas dos 26 estados e do distrito federal em um único relatório para apreciação na conferência nacional. Essas propostas são selecionadas a partir dos seguintes critérios: (1) seu conteúdo deve comparecer no documento de mais de 2 (dois) Estados da federação; (2) as demandas e expressões devem ser regionais, isto é, devem ser também apontadas por outros Estados da respectiva região; e (3) os conteúdos devem apresentar os princípios, diretrizes e objetivos da política de assistência social.

A conferência nacional segue a mesma dinâmica interna das conferências municipais e estaduais, sendo composta pela Plenária Inicial, por GTs - neste caso, 24 - e pela Plenária Final (Quadro 6). Nos GTs discute-se o caderno de resoluções com as propostas das conferências estaduais, que podem ser aprovadas integralmente ou com alteração ou podem ser rejeitadas. Neste espaço, os delegados também podem apresentar uma nova proposta por eixo temático. Para compor o documento final que é apreciado na Plenária, porém, as propostas devem ser aprovadas por 50\% mais um dos delegados presentes em cada GT e serem aprovadas por, no mínimo, 20\% dos GTs (no caso da $8^{\text {a }}$ Conferência de Assistência Social, por 5 Grupos de Trabalho).

As propostas que atendem a esses critérios são sistematizadas em um documento único pela Comissão de Relatoria para ser discutido e deliberado na plenária final, cuja dinâmica compreende: (1) a leitura das propostas oriundas das Conferências dos Estados e do Distrito Federal, (2) a leitura do Relatório consolidado das propostas dos GTs; (3) a apresentação dos destaques solicitados; e (4) a apresentação de uma defesa a favor e uma contrária desses destaques, quando for o caso. As propostas destacadas devem ser aprovadas por maioria simples dos votos. As demais são consideradas como aprovadas

13 A etapa estadual sempre é precedida de 12 conferências regionais, mas, no caso de 2009, por causa da $\mathrm{H} 1 \mathrm{~N} 1$ as conferencias regionais foram suspensas e o número de delegados foi reduzido. 
por unanimidade da plenária, sem que haja votação. As deliberações aprovadas são publicadas no Diário Oficial da União pelo CNAS, no prazo de 90 dias, a contar do seu encerramento e disponibilizadas na página eletrônica deste órgão.

Quadro 6 - Etapas das Conferências de Assistência Social

\begin{tabular}{c|c|c|c}
\hline variável & municipal & estadual & nacional \\
\hline etapas & $\begin{array}{c}\text { 9 Pré-Conferências regionais } \\
\text { preparatórias; }\end{array}$ & $\begin{array}{c}12 \text { Conferências Regionais*; } \\
\text { Conferências Municipais; }\end{array}$ & $\begin{array}{c}\text { Conferências Estaduais e } \\
\text { do Distrito Federal; }\end{array}$ \\
\hline $\begin{array}{c}\text { dinâmica } \\
\text { interna }\end{array}$ & $\begin{array}{c}\text { Plenária Inicial; } \\
\text { prupos de Trabalho; } \\
\text { Plenária Final }\end{array}$ & $\begin{array}{c}\text { Plenária Inicial; } \\
20 \text { Grupos de Trabalho; } \\
\text { Plenária Final }\end{array}$ & $\begin{array}{c}\text { Plenária Inicial; } \\
24 \text { Grupos de Trabalho, } \\
\text { Plenária Final }\end{array}$ \\
\hline plenária final & $\begin{array}{c}\text { Discussão e aprovação das } \\
\text { propostas aprovadas nos } \\
\text { GTs por maioria simples dos } \\
\text { delegados. }\end{array}$ & $\begin{array}{c}\text { Discussão e aprovação das } \\
\text { propostas aprovadas nos } \\
\text { GTs por maioria simples dos } \\
\text { delegados. }\end{array}$ & $\begin{array}{c}\text { Discussão e aprovação das } \\
\text { propostas aprovadas nos } \\
\text { GTs por maioria simples } \\
\text { dos delegados. }\end{array}$ \\
\hline
\end{tabular}

* Entendendo como regional aquela convocada por dois ou mais Executivos municipais, ficando garantido a cada município participante o número de delegados previsto pelo RI.

Fonte: Regimento Interno das Conferências de Assistência Social.

Assim como as CAS, as Conferências de Políticas para Mulheres ocorrem em etapas encadeadas (Quadro 7). No âmbito municipal, são realizadas Pré-Conferências preparatórias, que são abertas ao público em geral. Estas são seguidas por Conferências Municipais, que são organizadas pela Comissão (1) Organizadora; (2) Temática e de Relatoria; (3) de Infraestrutura; (4) de Articulação e Mobilização; (5) de Comunicação e Informação, e apresentam uma dinâmica que envolve a Plenária de Abertura, GTs - neste caso, 12 - e a Plenária Final, cujo produto é o relatório final.

Os GTs são compostos por uma coordenação e por relatores, escolhidos pelo próprio grupo. Os últimos integram, ao final do processo de discussão e de deliberação nesses espaços, a equipe de redação do documento síntese que será debatido na Plenária Final. Para aparecer neste documento, a proposta deve ter aprovação de, no mínimo, 20\% das participantes de cada GT.

Na plenária final, cada proposta é votada separadamente e deve ser aprovada por maioria simples dos delegados presentes. As propostas aprovadas compõem o relatório final do encontro, o qual é elaborado em versão resumida de, no máximo, 3 laudas, seguindo roteiro previamente defini- 
do pela Comissão Organizadora Estadual e pela Comissão de Relatoria, e é encaminhado para a Comissão Organizadora da conferência estadual.

Assim como os encontros municipais, as conferências estaduais são organizadas pela Comissão (1) Organizadora, (2) Técnica (ou temática); (3) Administrativa e (4) de Comunicação e por (5) subcomissões, e são compostas por uma Plenária Inicial, Grupos de Trabalho - no caso, 5 GTs apenas - e por uma plenária final (Quadro 7). Ademais, os GTs são formados por uma coordenação e por relatores, escolhidos pelo próprio grupo. Nele, as propostas do documento e as novas propostas apresentadas são debatidas e votadas e devem ser aprovadas por maioria simples dos presentes para compor o relatório final. Do mesmo modo, na plenária final, cada proposta deve ser aprovada por maioria simples dos delegados presentes. As propostas aprovadas são reunidas em um único documento, com no máximo 10 laudas, pela comissão organizadora, o qual é encaminhado para a SPM. A esta compete sistematizar em um único documento as propostas dos 26 estados e do distrito federal para apreciação na etapa nacional.

A Conferência Nacional apresenta a mesma dinâmica das etapas anteriores, que se inicia com uma plenária, segue com a discussão e a deliberação das propostas em GTs - no caso desta etapa, foram 24 GTs - e encerra as atividades com uma plenária final (Quadro 7).

Nos GTs, as propostas devem ser aprovadas por 20\% dos participantes do grupo para que seja encaminhada para a Comissão de Relatoria. Essa comissão reúne todas as propostas em um documento único, que é discutido na plenária final. As propostas que obtiveram aprovação em $70 \%$ do total dos grupos de trabalho são consideradas aprovadas pela conferência, mediante referendo do plenário. As aprovadas em um ou mais grupos são deliberadas em plenário, desde que não contrariem as recomendações já aprovadas por referendo. Na plenária, as propostas e as moções devem ser aprovadas por maioria simples dos delegados presentes. As moções são apresentadas exclusivamente por delegadas/os, devendo ser de âmbito ou repercussão nacional e devendo ser assinadas por, no mínimo, 10\% do total de delegadas/os.

O relatório final com as propostas e moções aprovadas é elaborado pela Comissão Temática e de Relatoria, coordenada pela SPM, em até 45 dias após o término da conferência. Antes de sua divulgação, porém, ele deve ser referendado pelo Conselho Nacional, sendo, posteriormente, encaminhado às delegações estaduais e municipais. 
Quadro 7 - Etapas da 2a Conferência de Políticas para Mulheres

\begin{tabular}{c|c|c|c}
\hline variável & municipal & estadual & nacional \\
\hline etapas & $\begin{array}{c}\text { 9 Pré-Conferências regio- } \\
\text { nais preparatórias; }\end{array}$ & $\begin{array}{c}\text { Conferências Regionais, } \\
\text { Conferências Municipais; }\end{array}$ & $\begin{array}{c}\text { Conferências Estaduais e do } \\
\text { Distrito Federal; }\end{array}$ \\
\hline $\begin{array}{c}\text { dinâmica } \\
\text { interna }\end{array}$ & $\begin{array}{c}\text { Plenária Inicial; } \\
12 \text { Grupos de Trabalho; } \\
\text { Plenária Final; }\end{array}$ & $\begin{array}{c}\text { Plenária Inicial; } \\
5 \text { Grupos de Trabalho; Plenária } \\
\text { Final; }\end{array}$ & $\begin{array}{c}\text { Plenária Inicial; } \\
24 \text { Grupos de Trabalho, } \\
\text { Plenária Final; }\end{array}$ \\
\hline $\begin{array}{c}\text { processo } \\
\text { decisório } \\
\text { na plenária } \\
\text { final }\end{array}$ & $\begin{array}{c}\text { Discussão e aprovação das } \\
\text { propostas aprovadas nos } \\
\text { GTs por maioria simples dos } \\
\text { delegados. }\end{array}$ & $\begin{array}{c}\text { Discussão e aprovação das } \\
\text { propostas aprovadas nos } \\
\text { GTs por maioria simples dos } \\
\text { delegados. }\end{array}$ & $\begin{array}{c}\text { Discussão e aprovação das } \\
\text { propostas aprovadas em mais } \\
\text { de um GT por maioria simples } \\
\text { dos delegados. }\end{array}$ \\
\hline
\end{tabular}

Fonte: Regimento Interno das Conferências de Políticas para Mulheres.

\section{Atores nas CAS e nas Conferências de Políticas para Mulheres}

O $8^{\circ}$ encontro municipal de Assistência Social mobilizou 2.000 participantes em Belo Horizonte, em 2009, dos quais 418 eram delegados eleitos nas pré-conferências, representantes de órgãos governamentais, entidades de classe, conselhos, associações, sindicatos de profissionais da área, usuários e interessados no tema. Estes foram escolhidos a partir dos seguintes critérios: (a) 1 delegado para cada 4 participantes credenciados das pré-conferências; (b) 2 delegados por instituições de base municipal inscritas no CMAS/BH, escolhidos através de encontros ou reuniões realizadas por essas entidades e registradas em ata; (c) até 2 delegados representantes do Conselho Estadual de Assistência Social (CEAS), do Fórum Mineiro de Assistência Social, do Conselho Estadual de Segurança Alimentar, do Conselho do Bolsa Família, do Conselho Regional de Serviço Social (CRESS), da União dos Conselhos da Grande BH e do COGEMAS; (d) até 4 delegados representantes de cada secretaria, autarquia, empresa pública, órgãos diretos e indiretos da administração municipal; (e) até 4 delegados oriundos da SEDESE; e (f) até 2 delegados representantes do MDS, INSS, CNAS, Ministério Público e do Poder Judiciário conforme retratado no Quadro 8.

A $8^{\text {a }}$ Conferência Estadual em Minas Gerais, por sua vez, contou com a participação de 1.000 pessoas, sendo 896 delegados e 104 convidados. Dos 896 delegados, 91 eram delegados natos e 805 foram eleitos nas conferências 
municipais, a partir dos seguintes critérios: 1) paridade entre representação governamental e representação da sociedade civil; 2) participação dos usuários ou representantes de usuários, em um total correspondente a 40\% das vagas destinadas à sociedade civil; 3) simetria entre as demais categorias que compõem o quadro dos atores da Política de Assistência Social; e 4) representatividade do delegado, isto é, sua ligação com sua categoria de representação.

Dos 91 delegados natos, 40 eram conselheiros titulares e suplentes do CEAS, 2 eram representantes da Secretaria Executiva deste Conselho, 10 representavam a SEDESE, 5, o Colegiado de Gestores Municipais de Assistência Social e 34 eram representantes das Uniões de Conselhos Municipais de Assistência Social, oficializados no CEAS, sendo 2 vagas para cada União. Dos 805 delegados eleitos segundo os critérios supracitados, 50\% representavam órgãos governamentais, sendo $70 \%$ de gestores e 30\% outros, e 50\% eram representantes da sociedade civil, sendo $30 \%$ trabalhadores, $30 \%$ servidores e 40\% usuários (Quadro 8).

Já a $8^{\text {a }}$ Conferência Nacional mobilizou 1.902 participantes, sendo 1.422 delegados com direito a voz e a voto, 280 convidados do Conselho Nacional de Assistência Social com direito a voz e 200 observadores também somente com direito a voz. Dos 1.422 delegados, 36 eram conselheiros nacionais, 1.296 eram representantes eleitos nas conferências municipais e estaduais e 88 eram representantes do governo federal. Estes foram escolhidos durante as conferências estaduais e do Distrito Federal, observando a paridade de representação entre governo e sociedade civil. Para determinar a quantidade de delegados estaduais e seus respectivos suplentes por estado, foram considerados os seguintes parâmetros: (a) 4 delegados para cada estado com menos de $2 \%$ do total da população brasileira, (b) 6 delegados para os estados com $2 \%$ a $5 \%$ do total da população brasileira; e (c) 8 delegados para cada estado com mais de $5 \%$ do total da população brasileira. Como nas conferências estaduais, a escolha dos delegados e de seus suplentes para participar do encontro nacional segue critérios de proporcionalidade em relação ao porte do município e às categorias de representação dos delegados, quais sejam: a quantidade de municípios do estado; a quantidade de municípios em Gestão Básica ou Plena no estado; e a população residente no estado (Quadro 8). 
Quadro 8 - Atores e forma de seleção da 8 a Conferência de Assistência Social

\begin{tabular}{|c|c|c|c|}
\hline variável & municipal & estadual & nacional \\
\hline $\begin{array}{c}\text { total de } \\
\text { participantes }\end{array}$ & $2.000^{*}$ & 1.000 & 1.902 \\
\hline $\begin{array}{c}\text { total de } \\
\text { delegados }\end{array}$ & 418 & 896 & 1.422 \\
\hline $\begin{array}{c}\text { composição da } \\
\text { participação } \\
\text { dos delegados }\end{array}$ & $\begin{array}{l}50 \% \text { Representantes de } \\
\text { órgãos governamentais } \\
\text { e } 50 \% \text { de representantes } \\
\text { da sociedade civil, envol- } \\
\text { vendo entidades de classe, } \\
\text { conselhos, associações, } \\
\text { sindicatos de profissionais } \\
\text { da área, usuários e interes- } \\
\text { sados no tema. }\end{array}$ & $\begin{array}{l}805 \text { delegados eleitos nas } \\
\text { conferências municipais } \\
91 \text { delegados natos, sendo } 40 \\
\text { conselheiros do CEAS, } 2 \text { repre- } \\
\text { sentantes da Secretaria Executiva } \\
\text { deste Conselho, } 10 \text { da SEDESE, } 5 \text { do } \\
\text { Colegiado de Gestores Municipais de } \\
\text { Assistência Social e } 34 \text { represen- } \\
\text { tantes das Uniões de Conselhos } \\
\text { Municipais de Assistência Social. }\end{array}$ & $\begin{array}{c}36 \text { conselheiros } \\
\text { nacionais. } \\
1.296 \text { representantes } \\
\text { eleitos nas } \\
\text { conferências } \\
\text { municipais } \\
\text { e estaduais. } \\
88 \text { representantes do } \\
\text { governo federal. }\end{array}$ \\
\hline $\begin{array}{c}\text { forma de } \\
\text { seleção dos } \\
\text { delegados para } \\
\text { etapa seguinte }\end{array}$ & $\begin{array}{c}\text { Delegados da sociedade } \\
\text { civil: varia de acordo com a } \\
\text { quantidade de participan- } \\
\text { tes das pré-conferências (1 } \\
\text { delegado eleito para cada } \\
4 \text { participantes). } \\
\text { Delegados do governo: } \\
\text { varia de acordo com } 0 \\
\text { número de representantes } \\
\text { eleitos de cada instituição } \\
\text { pública (entre } 2 \text { e } 4 \text { por } \\
\text { órgão). }\end{array}$ & $\begin{array}{l}\text { Paritária, sendo } 50 \% \text { de delegados } \\
\text { da sociedade civil e } 50 \% \text { do } \\
\text { governo, obedecida a proporçãa em } \\
\text { relação ao porte do municipio e à } \\
\text { categoria de referência do delegado. }\end{array}$ & Não se aplica \\
\hline
\end{tabular}

* Dado informado verbalmente por uma representante do Conselho Municipal da Assistência Social de BH. Fonte: Regimento Interno das Conferências de Assistência Social, CEAS e SEDESE (2011).

A $2^{\text {a }}$ Conferência Municipal de Políticas para Mulheres em Belo Horizonte, em 2007, contou com a participação de representantes de entidades públicas, tais como a Coordenadoria Municipal dos Direitos da Mulher, o Conselho Municipal dos Direitos da Mulher de Belo Horizonte e órgãos governamentais e do Legislativo; e de representantes de movimentos sociais de mulheres negras, lésbicas, profissionais do sexo, mulheres com deficiência 
e jovens, de sindicatos, associações e outras entidades da área. As delegadas dessa Conferência foram escolhidas nas pré-conferências que ocorreram no âmbito das 9 secretarias municipais de gestão regional. Para cada 8 participantes nas Pré-Conferências, foi eleita 1 delegada. No total, foram escolhidas 40 delegadas para a 2a Conferência Municipal (Quadro 9).

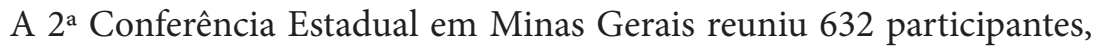
dentre eles, 532 delegados natos (titulares e suplentes do Conselho Estadual da Mulher - CEM - e parlamentares mulheres da ALMG e delegadas eleitas nos encontros municipais). Os representantes governamentais foram indicados pelo Executivo Municipal, dentre aqueles que participaram da etapa municipal. Os delegados da sociedade civil, por sua vez, foram eleitos por maioria simples na Plenária final da conferência municipal, obedecendo aos critérios de proporcionalidade territorial, estabelecidos no regimento interno da conferência estadual, de modo que: (a) municípios com até 50.000 teriam direito a 1 delegada da sociedade civil e 1 do Poder Publico Municipal, (b) municípios com 50.001 a 100.000 seriam, respectivamente, 2 e 1, (c) de 100.001 a 150.000 seriam 3 delegadas da sociedade civil para 1 do poder publico, (d) de 150.001 a 200.000, 4 para 1, (e) de 200.001 a 300.000 habitantes, 6 representantes da sociedade civil para 2 governamentais , (f) de 300.001 a 500.000, 10 delegadas da sociedade civil e 3 do poder publico, e (g) de 500.001 a 1.000 .000 habitantes seriam 20 para 6. Para os municípios com mais de 1.000.000 de habitantes, como Belo Horizonte, foram eleitas 50 delegadas representantes da sociedade civil e 15 representantes do Poder Público Municipal, respeitando a proporção de 60\% e 40\% (30\% de representantes municipais e $10 \%$ de representantes estaduais), respectivamente.

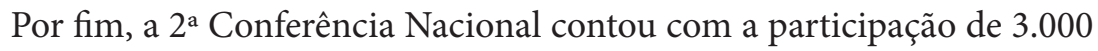
pessoas, sendo 2.800 delegados, com direito de voz e voto, e 200 convidados, autoridades e representantes de entidades nacionais e internacionais, com direito a voz. Dos 2.800 delegados, 2.306 foram eleitos nas conferências estaduais, 69 eram delegados natos, integrantes do Conselho Nacional dos Direitos da Mulher, e 425 eram delegadas/os dos diferentes órgãos do Governo Federal indicadas/os para este fim. Do total de delegados eleitos na etapa estadual, 1.383 (60\% do total de delegados eleitos) eram representantes da sociedade civil, 690 (30\%) dos governos municipais e 233 (10\%) representavam os governos estaduais. O estado de Minas Gerais contou com a participação de 183 delegados, sendo 110 (60\%) de representantes da socie- 
dade civil, 55 (30\%) do poder público municipal e 18 (10\%) representantes do poder público estadual.

Quadro 9 - Atores e forma de seleção da 2a Conferência de Políticas para Mulheres

\begin{tabular}{|c|c|c|c|}
\hline variável & municipal & estadual & nacional \\
\hline $\begin{array}{c}\text { total de } \\
\text { participantes }\end{array}$ & s/dado & 632 & 3.000 \\
\hline $\begin{array}{c}\text { total de } \\
\text { delegados }\end{array}$ & 360 & 532 & 2.800 \\
\hline $\begin{array}{l}\text { composição } \\
\text { da partici- } \\
\text { pação dos } \\
\text { delegados }\end{array}$ & $\begin{array}{l}40 \% \text { representantes } \\
\text { governamentais e } \\
60 \% \text { representantes } \\
\text { de movimentos so- } \\
\text { ciais, de sindicatos, } \\
\text { associações e outras } \\
\text { entidades da área. }\end{array}$ & $\begin{array}{c}213 \text { representantes } \\
\text { governamentais ( } 30 \% \\
\text { municipal e } 10 \% \text { estadual) } \\
319 \text { representantes da } \\
\text { sociedade civil }(60 \%) \text {. }\end{array}$ & $\begin{array}{c}2.306 \text { oriundos das conferências } \\
\text { estaduais, sendo: } 1.383(60 \%) \\
\text { da sociedade civil, } 690 \text { ( } 30 \%) \text { dos } \\
\text { governos municipais e } 233 \text { (10\%) } \\
\text { dos governos estaduais. } \\
69 \text { delegados natos, } \\
\text { integrantes do CNDM } \\
425 \text { delegadas/os dos diferentes } \\
\text { órgãos do Governo Federal. }\end{array}$ \\
\hline $\begin{array}{l}\text { forma de } \\
\text { seleção dos } \\
\text { delegados } \\
\text { para etapa } \\
\text { seguinte }\end{array}$ & $\begin{array}{l}60 \% \text { de represen- } \\
\text { tantes da sociedade } \\
\text { civil e } 40 \% \text { de dele- } \\
\text { gados dos governos } \\
\text { municipais, obede- } \\
\text { cendo critérios de } \\
\text { proporcionalidade } \\
\text { territorial. }\end{array}$ & $\begin{array}{l}60 \% \text { de representantes } \\
\text { da sociedade civil e } 40 \% \\
\text { de delegados do governo } \\
\text { (10\% dos governos estaduais } \\
\text { e } 30 \% \text { dos municipais), } \\
\text { obedecendo critérios de } \\
\text { proporcionalidade territorial. }\end{array}$ & Não se aplica \\
\hline
\end{tabular}

Fonte: Regimento Interno das Conferências de Políticas para Mulheres, CMPM, CEM e ALMG (2011).

\section{Resoluções das CAS e das Conferências de Políticas para Mulheres}

Os 418 delegados da $8^{\text {a }}$ Conferência Municipal de Assistência Social em BH aprovaram 23 deliberações referentes aos 4 eixos propostos. Na etapa estadual, as propostas discutidas foram deliberadas nas conferências municipais e, por isso, diversas propostas aprovadas nesta etapa estavam presentes entre as 24 deliberações aprovadas no encontro de Minas Gerais. Na etapa nacional, após a discussão de 383 propostas provenientes de todos os estados da federação, foram aprovadas 57, sendo 15 delas relativas ao primeiro eixo temático, 10 ao 
segundo eixo, 10 ao terceiro eixo, 11 ao quarto eixo e 11 relativas aos princípios, diretrizes e objetivos da política de assistência social (Quadro 10).

Destas, algumas delas foram discutidas e aprovadas na etapa de Belo Horizonte e de Minas Gerais, como, por exemplo, (1) a demanda por promoção de capacitação permanente para gestores, entidades de assistência social, trabalhadores da área, conselheiros e usuários; (2) metas prevendo uma participação mais efetiva da sociedade civil, a publicização das informações e ações da política de assistência social para o público alvo e a ampliação dos recursos financeiros e orçamentários da política de assistência, e (3) a ampliação dos CRAS para melhorar o atendimento aos usuários e fortalecer as relações institucionais entre gestores, usuários e trabalhadores.

Quadro 10 - Processo decisório e resoluções das Conferências de Assistência Social

\begin{tabular}{|c|c|c|c|}
\hline variável & municipal & estadual & nacional \\
\hline resoluções & $\begin{array}{l}\text { Aprovadas } 23 \\
\text { deliberações } \\
\text { em } 4 \text { eixos } \\
\text { temáticos. }\end{array}$ & $\begin{array}{c}\text { Aprovadas } 3 \\
\text { deliberações por } \\
\text { subtema, num total } \\
\text { de } 24 \text { deliberações. }\end{array}$ & $\begin{array}{c}\text { Aprovadas } 57 \text { deliberações, sendo } 15 \text { relativas ao } \\
\text { primeiro eixo temático, } 10 \text { do segundo eixo, } 10 \text { do } \\
\text { terceiro eixo, e } 11 \text { do quarto eixo, e } 11 \text { delibera- } \\
\text { ções relativas aos princípios, diretrizes e objetivos } \\
\text { da política de assistência social. }\end{array}$ \\
\hline
\end{tabular}

Fonte: Relatório final das Conferências de Assistência Social.

A $2^{\text {a }}$ Conferência Municipal de Políticas para Mulheres em Belo Horizonte aprovou cerca de 210 deliberações, nos cinco eixos temáticos propostos: (1) Autonomia e igualdade no mundo do trabalho, (2) Educação inclusiva e não sexista, (3) Saúde das mulheres, direitos sexuais e direitos reprodutivos, (4) Enfrentamento da violência contra as mulheres e (5) Mulher e poder: participação social na política.

Na Conferência Estadual, foram analisadas, pelos GTs, 315 propostas aprovadas nos encontros municipais e/ou regionais. Dessas, 49 foram votadas como prioritárias e foram encaminhadas à Conferência Nacional. As demais foram enviadas ao governo estadual e federal como contribuições do encontro.

$\mathrm{Na}$ etapa nacional, as resoluções e propostas das conferências estaduais foram discutidas e deliberadas em GTs e na Plenária Final. Nesta, foram aprovadas prioridades nos cinco eixos do Plano Nacional de Política para Mulheres (PNPM) e criados seis novos eixos: (1) participação política das mulheres e igualdade em todos os espaços de poder; (2) desenvolvimento 
sustentável; (3) direito das mulheres à terra e à moradia; (4) cultura, comunicação e mídia não discriminatória; (5) enfrentamento de todas as formas de discriminação, entre elas o racismo, o sexismo e a lesbofobia; e (6) enfrentamento das desigualdades que atingem as mulheres jovens e idosas. No total, foram aprovadas 91 metas, 56 prioridades e 394 ações nesses 11 eixos temáticos que compõem o $2^{\circ}$ PNPM.

Dentre as propostas aprovadas, várias foram aprovadas na etapa municipal e estadual, como, por exemplo, (1) o apoio solicitado pelos estados e municípios para a construção de equipamentos sociais, para facilitar a inserção e permanência das mulheres no mercado de trabalho; (2) a promoção ou apoio à realização de cursos de capacitação técnica e gerencial para as mulheres; (3) a instituição de redes de atendimento às mulheres em situação de violência; (4) a promoção de ações preventivas em relação à violência doméstica e sexual; e (5) a capacitação dos profissionais das áreas de segurança pública, saúde, educação e assistência psicossocial na temática da violência de gênero (Quadro 11).

Quadro 11 - Processo decisório e resoluções da 2a Conferência de política para Mulheres

\begin{tabular}{c|c|c|c}
\hline variável & municipal & estadual & nacional \\
\hline resoluções & $\begin{array}{c}\text { Aprovadas 210 deliberações } \\
\text { em 5 eixos temáticos. }\end{array}$ & $\begin{array}{c}\text { Encaminhadas 49 das 315 } \\
\text { propostas para a conferência } \\
\text { nacional. }\end{array}$ & $\begin{array}{c}\text { Aprovadas } 91 \text { metas, 56 } \\
\text { prioridades e 394 ações em } \\
11 \text { eixos temáticos. }\end{array}$ \\
\hline
\end{tabular}

Fonte: Relatório final das conferências de Políticas para Mulheres.

\section{Notas conclusivas}

Este artigo avaliou comparativamente as Conferências de Assistência Social e de Políticas para Mulheres, buscando aferir se e como estes espaços formam um sistema integrado de participação e deliberação entre os diferentes níveis da federação.

Com o intuito de precisar os elementos desse sistema, analisamos, na primeira seção deste artigo, as inovações no interior do modelo de democracia deliberativa. Mostramos que o novo "turn" no interior desta abordagem (Faria, 2010) tem como uma das preocupações centrais localizar a deliberação dentro de um processo decisório mais amplo, buscando compatibilizar diferentes espaços compostos por atores e tipos de ação também diferentes.

A análise sobre políticas públicas (seção 2) visou mostrar o debate no interior deste campo sobre a centralidade da participação e da deliberação 
nos determinantes do processo decisório, particularmente no processo de elaboração da agenda governamental. Neste caso, no lugar da preocupação com coordenação de diversas formas de ação em espaços diferentes, buscou-se ressaltar a importância de múltiplos agentes em comunidades de políticas ou coalizões de defesa para a determinação da agenda decisória. O debate acerca da centralidade da dimensão interativa através da qual estas comunidades e coalizões são formadas, os problemas são estruturados e a agenda possivelmente mudada, chama atenção para o importante papel desempenhado nestes processos pelos discursos e narrativas, além das crenças e ideias. Narrativas e discursos revelam-se importantes no processo de descoberta e formatação dos problemas, bem como na orientação das coalizões que se formarão.

Tais abordagens estão, portanto, vinculadas não só em função da ênfase atribuída à inclusão de novos atores na determinação das políticas públicas em suas diferentes etapas - elaboração, implementação, gestão e controle - mas também em função da preocupação com as formas apropriadas de envolver tais comunidades ou coalizões. A dimensão argumentativa, mais que a agregativa, busca responder exatamente esta última questão, ou seja, a qualidade das relações estabelecidas entre o conjunto de atores no interior destes espaços.

Ironicamente, parece ter sido esta percepção que balizou o governo Vargas ao propor a primeira Conferência de Saúde em 1937, cujo objetivo era "facilitar o conhecimento do Governo Federal acerca das atividades relativas à saúde e de orientá-lo na execução dos serviços locais de saúde”. A disseminação de ideias, opiniões e experiências narradas pelas comunidades de atores vinculados à área de saúde poderia, acreditava-se, racionalizar ações governamentais nesta área e, deste modo, elaborar decisões mais eficazes. Em um contexto político radicalmente diferente, esta mesma percepção serviu de inspiração para o governo Lula realizar e expandir as Conferências para quase todas as área de políticas públicas.

Não obstante, em que pese à importância da inspiração que balizou tais realizações, a legitimidade dessas ações não reside em si mesmo e, por isto, aferir em que medida tais Conferências são inclusivas, produzem deliberações autênticas e resultados vinculantes, conformando, assim, sistemas integrados de participação e deliberação.

Para tal, analisamos comparativamente objetivos, estrutura, atores, e resultados das $7^{\mathrm{a}}$ e $8^{\mathrm{a}}$ Conferências de Assistência Social e a $2^{\mathrm{a}}$ Conferência de Políticas para Mulheres nos diferentes níveis da federação. 
Os quadros 12 e 13 a seguir sintetizam as principais variáveis analisadas neste artigo sobre as Conferências Nacionais de Assistência Social e de Políticas para Mulheres

\section{Quadro 12 - Resumo para Conferências de Assistência Social}

\begin{tabular}{|c|c|c|c|}
\hline \multirow{2}{*}{ variável } & \multicolumn{3}{|c|}{ etapas } \\
\hline & municipal & estadual & nacional \\
\hline $\begin{array}{l}\text { objetivo } \\
\text { principal }\end{array}$ & $\begin{array}{l}\text { Avaliar e propor diretrizes } \\
\text { para o aperfeiçoamento } \\
\text { do Sistema Único de } \\
\text { Assistência Social (SUAS) } \\
\text { na perspectiva da } \\
\text { participação e do controle } \\
\text { social. }\end{array}$ & $\begin{array}{c}\text { Avaliar e propor diretrizes } \\
\text { para } 0 \text { aperfeiçoamento do } \\
\text { Sistema Único de Assistência } \\
\text { Social (SUAS) na perspectiva } \\
\text { da participação e do controle } \\
\text { social. }\end{array}$ & $\begin{array}{l}\text { Avaliar e propor diretrizes para } \\
0 \text { aperfeiçoamento do Sistema } \\
\text { Único de Assistência Social (SUAS) } \\
\text { na perspectiva da participação e } \\
\text { do controle social. }\end{array}$ \\
\hline $\begin{array}{l}\text { dinâmica } \\
\text { interna }\end{array}$ & $\begin{array}{l}\text { Plenária Inicial; } \\
4 \text { Grupos de Trabalho; } \\
\text { Plenária Final. }\end{array}$ & $\begin{array}{l}\text { Plenária Inicial; } \\
20 \text { Grupos de Trabalho; } \\
\text { Plenária Final. }\end{array}$ & $\begin{array}{c}\text { Plenária Inicial; } \\
24 \text { Grupos de Trabalho, Plenária } \\
\text { Final. }\end{array}$ \\
\hline $\begin{array}{l}\text { processo } \\
\text { decisório }\end{array}$ & $\begin{array}{l}\text { Discussão e aprovação das } \\
\text { propostas aprovadas nos } \\
\text { GTs por maioria simples } \\
\text { dos delegados. }\end{array}$ & $\begin{array}{l}\text { Discussão e aprovação das } \\
\text { propostas aprovadas nos } \\
\text { GTs por maioria simples dos } \\
\text { delegados. }\end{array}$ & $\begin{array}{l}\text { Discussão e aprovação das } \\
\text { propostas aprovadas nos GTs por } \\
\text { maioria simples dos delegados. }\end{array}$ \\
\hline $\begin{array}{c}\text { total de } \\
\text { delegados }\end{array}$ & 418 & 896 & 1.422 \\
\hline $\begin{array}{l}\text { compo- } \\
\text { sição da } \\
\text { participa- } \\
\text { ção dos } \\
\text { delegados } \\
\text { por } \\
\text { segmento }\end{array}$ & $\begin{array}{l}50 \% \text { Representantes de } \\
\text { órgãos governamentais e } \\
50 \% \text { de representantes da } \\
\text { sociedade civil, envolven- } \\
\text { do entidades de classe, } \\
\text { conselhos, associações, } \\
\text { sindicatos de profissio- } \\
\text { nais da área, usuários e } \\
\text { interessados no tema. }\end{array}$ & $\begin{array}{l}805 \text { delegados eleitos nas } \\
\text { conferências municipais } \\
91 \text { delegados natos, sendo } \\
40 \text { conselheiros do CEAS, } 2 \\
\text { representantes da Secretaria } \\
\text { Executiva deste Conselho, } 10 \\
\text { da SEDESE, } 5 \text { do Colegiado } \\
\text { de Gestores Municipais } \\
\text { de Assistência Social e } 34 \\
\text { representantes das Uniões } \\
\text { de Conselhos Municipais de } \\
\text { Assistência Social. }\end{array}$ & $\begin{array}{l}36 \text { conselheiros nacionais. } \\
1.296 \text { representantes eleitos } \\
\text { nas conferências municipais e } \\
\text { estaduais. } \\
88 \text { representantes do governo } \\
\text { federal. }\end{array}$ \\
\hline resoluções & $\begin{array}{l}\text { Aprovadas } 23 \text { deliberações } \\
\text { em } 4 \text { eixos temáticos. }\end{array}$ & $\begin{array}{c}\text { Aprovadas } 3 \text { deliberações por } \\
\text { sub-tema, num total de } 24 \\
\text { deliberações. }\end{array}$ & $\begin{array}{l}\text { Aprovadas } 57 \text { deliberações, sendo } \\
15 \text { relativas ao primeiro eixo } \\
\text { temático, } 10 \text { do segundo eixo, } 10 \\
\text { do terceiro eixo, } 11 \text { do quarto eixo } \\
\text { e } 11 \text { deliberações relativas aos } \\
\text { princípios, diretrizes e objetivos } \\
\text { da política de assistência social. }\end{array}$ \\
\hline
\end{tabular}


Quadro 13 - Resumo para Conferências de Políticas para Mulheres

\begin{tabular}{|c|c|c|c|}
\hline \multirow{2}{*}{ variável } & \multicolumn{3}{|c|}{ etapas } \\
\hline & municipal & estadual & nacional \\
\hline objetivos & $\begin{array}{c}\text { Avaliar e aprimorar o } \\
\text { Plano Nacional de Políticas } \\
\text { para Mulheres (PNPM) na } \\
\text { perspectiva da participação } \\
\text { das mulheres em espaços } \\
\text { de poder. }\end{array}$ & $\begin{array}{l}\text { Avaliar e aprimorar o Plano } \\
\text { Nacional de Políticas para Mu- } \\
\text { lheres (PNPM) na perspectiva } \\
\text { da participação das mulheres } \\
\text { em espaços de poder. }\end{array}$ & $\begin{array}{c}\text { Avaliar e aprimorar o } \\
\text { Plano Nacional de Políticas } \\
\text { para Mulheres (PNPM) na } \\
\text { perspectiva da participação } \\
\text { das mulheres em espaços } \\
\text { de poder. }\end{array}$ \\
\hline $\begin{array}{l}\text { dinâmica } \\
\text { interna }\end{array}$ & $\begin{array}{c}\text { Plenária Inicial; } \\
12 \text { Grupos de Trabalho; } \\
\text { Plenária Final. }\end{array}$ & $\begin{array}{l}\text { Plenária Inicial; } \\
5 \text { Grupos de Trabalho; } \\
\text { Plenária Final. }\end{array}$ & $\begin{array}{l}\text { Plenária Inicial; } \\
24 \text { Grupos de Trabalho, } \\
\text { Plenária Final. }\end{array}$ \\
\hline $\begin{array}{l}\text { processo } \\
\text { decisório }\end{array}$ & $\begin{array}{l}\text { Discussão e aprovação das } \\
\text { propostas aprovadas nos } \\
\text { GTs por maioria simples dos } \\
\text { delegados. }\end{array}$ & $\begin{array}{l}\text { Discussão e aprovação das } \\
\text { propostas aprovadas nos } \\
\text { GTs por maioria simples dos } \\
\text { delegados. }\end{array}$ & $\begin{array}{l}\text { Discussão e aprovação das } \\
\text { propostas aprovadas em } \\
\text { mais de um GT por maioria } \\
\text { simples dos delegados. }\end{array}$ \\
\hline $\begin{array}{c}\text { total de } \\
\text { delegados }\end{array}$ & 360 & 532 & 2.800 \\
\hline $\begin{array}{l}\text { composição } \\
\text { da partici- } \\
\text { pação dos } \\
\text { delegados }\end{array}$ & $\begin{array}{l}40 \% \text { representantes } \\
\text { governamentais e } \\
60 \% \text { representantes de } \\
\text { movimentos sociais, de } \\
\text { sindicatos, associações e } \\
\text { outras entidades da área. }\end{array}$ & $\begin{array}{c}213 \text { representantes } \\
\text { governamentais } \\
\text { (30\% municipal e } 10 \% \\
\text { estadual) } 319 \text { representantes } \\
\text { da sociedade civil }(60 \%)\end{array}$ & $\begin{array}{l}2.306 \text { oriundos das confe- } \\
\text { rências estaduais, sendo: } \\
1.383(60 \%) \text { da sociedade } \\
\text { civil, } 690 \text { (30\%) dos gover- } \\
\text { nos municipais e } 233 \text { (10\%) } \\
\text { dos governos estaduais. } \\
69 \text { delegados natos, } \\
\text { integrantes do CNDM } \\
425 \text { delegadas/os dos di- } \\
\text { ferentes órgãos do Governo } \\
\text { Federal. }\end{array}$ \\
\hline resoluções & $\begin{array}{l}\text { Aprovadas } 210 \text { deliberações } \\
\text { em } 5 \text { eixos temáticos. }\end{array}$ & $\begin{array}{c}\text { Encaminhadas } 49 \text { das } 315 \\
\text { propostas para a conferência } \\
\text { nacional. }\end{array}$ & $\begin{array}{c}\text { Aprovadas } 91 \text { metas, } 56 \\
\text { prioridades e } 394 \text { ações em } \\
11 \text { eixos temáticos. }\end{array}$ \\
\hline
\end{tabular}

Fonte: Relatório final das conferências de Políticas para Mulheres.

Em relação aos objetivos das Conferências, constatamos que o temário de discussão das CAS e CPM em todas as etapas - das pré-conferências à Conferência Nacional - é o mesmo, mudando apenas aquilo que é atribuição específica de cada nível da federação. Por isso, como mostramos nos Quadros 
4 e 5, os objetivos específicos se repetem com vistas a precisar o plano de ação paras as políticas em questão.

No caso da CAS, esse plano se consubstancia no Caderno de Deliberações, no caso da CPM, no Plano Nacional de Políticas para as Mulheres.

É certo que tais objetivos são pré-determinados quando as Conferências são convocadas. Essa pré-determinação assume a forma de um roteiro de discussão, relativamente fechado, que baliza as discussões em torno das ações (AS) e/ou orientações (Mulheres) de políticas em cada área. Como tais roteiros são elaborados pela comunidade de atores que fazem parte da política, principalmente pelos Conselhos de Políticas Públicas que abrigam representantes governamentais e da sociedade civil, podemos afirmar que eles são coletivamente construídos.

A engenharia institucional dessas Conferências prevê, ainda, que as discussões em torno desses roteiros temáticos ocorram em múltiplos espaços encadeados que se diferenciam em termos de escala e em termos de morfologia.

Em termos de escala, todas as Conferências, em todos os níveis - local, municipal, estadual e nacional - apresentam Plenárias e Grupos de Trabalho que mudam em número e em quantidade de pessoas que deles participam.

Em termos morfológicos, Plenárias e Grupos de trabalho diferenciam entre si. As plenárias apresentam um tipo mais direto de ação, mais informal e, por vezes, mais conflitivo. Sua forma de decisão é sempre agregativa em função do próprio número de atores envolvidos. Os Grupos de Trabalho operam como grupos de discussões face a face através dos quais os atores têm a chance de apresentar suas opiniões e preferências, refletir e chegar às decisões por meio da troca de argumentos. Nesse momento, mesmo que constrangido pelo tempo, narrativas, ideias e questões são levantados podendo redefinir problemas, soluções e, às vezes, alianças estabelecidas. A forma agregativa de soluções dos problemas também ocorre nos Grupos, mas ela, em tese, deve ser precedida de discussões entre os atores em cena que podem, inclusive, incluir novas proposições aos roteiros que balizam tais discussões. Por meio de destaques, os atores envolvidos julgam publicamente as proposições, debatem e acordam sobre como mudá-las. Através das moções, eles publicizam e registram seus descontentamentos.

Neste sentido, tomando como base a imagem sugerida por Goodin (2008) de um sistema sequenciado de momentos deliberativos, as Conferências com- 
binam espaços mais amplos de apresentação e contestação de perspectivas, opiniões, crenças e interesses com espaços menores, propícios à discussão, à reflexão e decisão das mesmas. Elas apresentam espaços com regras diferentes que permitem tanto a ação direta, como a ação discursiva, dependendo do tamanho e da função que desempenham seus espaços internos. É verdade que grupos de trabalho compostos por 85 e 115 pessoas, como nos casos das CNAS e CNPM, respectivamente, podem ter suas capacidades deliberativas comprometidas, precisando ser não só subdivididos, como cuidadosamente mediados para que se obtenha uma deliberação autêntica.

Uma vez que a dinâmica representativa assume lugar de destaque na operacionalização das Conferências, sejam elas municipais, estaduais ou nacionais, as regras de seleção dos delegados são fundamentais enquanto medida de integração desses espaços e de capacidade para aferir o quanto "todos os afetados" são representados.

Como mostram os dados nos quadros anteriores, as CAS e CPM operam com representantes de segmentos da sociedade civil e do governo cuja proporcionalidade varia, bem como varia a forma de seleção dos mesmos. No caso da CAS, a composição dos delegados obedece à regra da paridade, ou seja, 50\% de representantes do segmento governamental e 50\% do segmento sociedade civil. Não obstante, dos $50 \%$ da sociedade civil, a regra discrimina positivamente os usuários destinando a eles $40 \%$ do total de vagas. No caso da CPM, a regra discrimina positivamente o segmento sociedade civil que possui $60 \%$ dos delegados, enquanto o segmento governamental possui os outros $40 \%$. Essa regra é válida para todo o território nacional.

A preocupação em discriminar positivamente o segmento sociedade civil, seja na figura do usuário do serviço ou da categoria sociedade civil como um todo, demonstra a intenção, pelo menos em tese, em incluir uma parte maior dos atores societários, considerados historicamente como "irrelevantes”. Não obstante, tais dados não nos permitem afirmar o quanto "dos mais afetados" é, na prática, incluído nesse processo.

Por fim, no que se refere aos resultados das conferências, isto é, às propostas debatidas e decididas nesses espaços, constatamos que em todas as Conferências os temas, objetivos e metas perpassam todas as etapas territoriais. Algumas dessas propostas seguem para o âmbito nacional e podem virar decisões. No caso das CAS, quando suas propostas assumem a forma de resoluções, depois de passar pelo processo deliberativo no CNAS, elas 
são publicadas no Diário oficial da União tornando-se, portanto, decisões vinculantes. Já as propostas da CPM, embora sejam igualmente discutidas em todas as etapas territoriais desta Conferência, não possuem caráter de resoluções, mas de recomendação para os governos, podendo, portanto, serem acatadas ou não.

É possível afirmar a partir da análise empreendida que as Conferências em tela possuem todos os requisitos institucionais para conformarem um sistema integrado de participação e deliberação nos moldes aqui propostos. Seus diferentes espaços internos são capazes de acomodar tipos diferentes de ação, assim como suas conexões externas são capazes de vincular uma etapa com a outra mediante uma metodologia que envolve roteiros temáticos e um processo representativo cuidadosamente construído. Do ponto de vista da engenharia institucional, isto não é pouco. Não obstante, embora acreditando que as regras importam na operacionalização desses espaços participativos, sabe-se que elas não são suficientes para predizer a qualidade da dinâmica participativa e deliberativa nestes sistemas que, como já ressaltado, devem envolver inclusão de todos, deliberação autêntica e produção de resultados vinculantes. Conforma-se, assim, uma agenda de pesquisa para lidar com mais uma inovação institucional do Brasil do século XXI.

\section{Referências bibliográficas}

BENHABIB, Sheila (org.). 1996. Democracy and difference: contesting the boundaries of the political. New Jersey: Pricenton University Press

CAMPBELL, John L. 2002. "Ideas, politics and public policy". Annual Review of Sociology, v. 28, p. 21-38.

COHEN, Joshua \& FUNG, Archon. 2004. "Radical democracy”. Swiss Journal of Political Science, v. 10, n. 4, p. 26-46.

COHEN, Joshua \& ROGERS, Joel. 1995. Associations and democracy. London: Verso.

COHEN, Joshua \& SABEL, Charles. 1997. "Directly-deliberative poyarchy”. European Law Journal, n. 3, p. 313-342.

COHEN, Michael D.; MARCH, James G. \& OLSEN. Johan P. 1972. “A garbage can model of organizational choice". Administrative Science Quarterly, v.17, n. 1, p. 1-25.

DRYZEK, John. 2010. Foundations and frontiers of deliberative governance. Oxford: Oxford University Press. 
FARIA, Cláudia F. \& RIBEIRO, Uriella C. 2010. "Entre o legal e o real: o que dizem as variáveis institucionais sobre os conselhos municipais de políticas públicas?". In: AVRITZER, L. (org.) A dinâmica da participação no Brasil. São Paulo: Cortez.

FARIA, Carlos Aurélio Pimenta de. 2003. "Idéias, conhecimento e políticas públicas: um inventário sucinto das principais vertentes analíticas recentes”. Revista Brasileira de Ciência Sociais, v.18, n. 51, p. 21-30.

FARIA, Cláudia F. 2010. "Do ideal ao real: as conseqüências das mudanças conceituais na teoria deliberativa”. Texto apresentado no $7^{\circ}$ Encontro da ABCP, Recife, 6 a 8 de agosto.

FISHKIN, James S. 1991. Democracy and deliberation: new directions for democratic reform. New Haven: Yale University Press.

FISCHER, Frank. 2003. Reframing public policy: discusive politics and deliberative practices. Oxford: Oxford University Press.

FUNG, Archon. 2005. "Representation, association, and participation: toward three dimensional democratic governance". Trabalho apresentado no Midwest Political Science Association Meeting, Chicago, 7 a 10 de abril.

FUNG, Archon \& WRIGHT, Erick O. 2003. Deepening democracy: institucional innovations in empowered participatory governance. London: Verso.

GASTIL, John \& LEVINE, Peter (eds.). 2005. The deliberative democracy handbook. New York: Jossey-Bass.

GOODIN, Robert. 2008. “Sequencing deliberative moments”. In: GOODIN, Robert (org.). Innovating democracy. Cambridge: Cambridge University Press.

HABERMAS, Jurgen. 1996. Between facts and norms. London: Polity Press. HAJER, Maarten A. \& Wagenaar, H. (eds.). 2003. Deliberative policy analysis: understanding governance in the network society. New York: Cambridge University Press.

HENDRIKS, Carolyne. 2006. "Integrated deliberation: civil society's dual role in deliberative democracy". Political Studies, v. 54, p. 486-508.

HOLZINGER, Katharina. 2005. "Context or conflict types: which determines the selection of communication mode". Acta Politica, v. 40, n. 2, p. 239-254.

JOHN, Peter. 1999. Analysing public policy: critical political studies. London: Continuum. 
KINGDON, John W. 2003. Agendas, alternatives, and public policies. New York: Longman.

MANSBRIDGE, James. 1999. "Everyday talk in the deliberative system". In: MACEDO, Stephen (ed.). Deliberative politics: essays on democracy and disagreement. New York: Oxford University Press.

2007. "Deliberative democracy or democratic deliberation?". In: ROSENBERG, Shawn W. (ed.) Deliberation, participation and democracy: can the people govern? New York: Palgrave Macmillan.

MANSBRIDGE, James et al. 2010. "The place of self-interest and the role of power in deliberative democracy". The Journal of Political Philosophy, v. 18 , n. 1, p. 64-100.

PAPADOPOULOS, Yannis \& WARIN, Philippe. 2007. "Are innovative, participatory, and deliberative procederus in policy making democratic and effective?" European Journal of Political Research, n. 46, p. 445-472.

ROSENBERG, Shawn W. 2007. Deliberation, participation and democracy: can the people decide? New York: Palgrave Macmillan.

SABATIER, Paul. 1988. "An advocacy coalition framework of policy change and the role of policy-orientated learning therein". Policy Sciences, v. 21, n. 2, p. 129-168.

SABATIER, Paul A. \& JENKINS-SMITH, Hank C. 1999. "The advocacy coalition framework: an assessment”. In: SABATIER, Paul A. (ed.). Theories of the policy process. Boulder: Westview Press.

SAYD, Jane Dutra; VIEIRA JUNIOR, Luiz \& VELANDIA, Israel Cruz. 1998. "Recursos humanos nas conferências nacionais de saúde (1941 a 1992)". Revista Saúde Coletiva, n.14, p. 167-179.

WARREN, Mark. 2007. Institucionalizing deliberative democracy. In: ROSENBERG, Shawn W. (org.) Deliberation, participation and democracy: can the people govern? New York: Palgrave Macmillan.

YOUNG, Iris M. 2000. Inclusion and democracy. Oxford: Oxford University Press.

\section{Resumo}

A teoria democrática contemporânea abriga pelo menos duas abordagens que vinculam a presença de espaços participativos à qualidade da democracia. Ambas, a abordagem participativa e a deliberativa, apostam na centralidade destes espaços para conferir 
legitimidade às decisões políticas que vinculam uma coletividade. Ao apostarem na centralidade da participação e da discussão para a legitimidade do processo decisório, tais abordagens tornam-se ferramentas analíticas úteis para analisarmos mais uma inovação democrática no Brasil contemporâneo: as Conferências de Políticas Públicas. O objetivo deste artigo é avaliar a estrutura institucional destas conferências para aferir como estes espaços integram diferentes tipos de ação e se eles conseguem formar um sistema integrado de participação e deliberação, entre os diferentes níveis da federação.

Palavras-chave: Conferências de Políticas Públicas; Participação; Deliberação; Inclusão.

\begin{abstract}
Contemporary democratic theory includes at least two approaches that link the presence of participatory spaces to the quality of democracy. Both the deliberative and participatory approaches consider these spaces important to the legitimacy of policy decisions that bond a collectivity. By investing in the centrality of participation and discussion to the legitimacy of decision making, such approaches become useful tools to analyze yet another democratic innovation of contemporary Brazil: Public Policy Conferences. The aim of this paper is to evaluate the institutional structure of those Conferences, in order to see how they combine different types of action and whether or not they form an integrated system of participation and decision between the different levels of the federation.
\end{abstract}

Key words: Public Policy Conferences; participation; decision; inclusion.

Recebido em maio de 2011.

Aprovado em julho de 2011. 